\title{
KAJIAN PARTISIPASI MASYARAKAT DALAM KEGIATAN PNPM MANDIRI DI KELURAHAN KLEAK KECAMATAN MALALAYANG KOTA MANADO
}

\author{
Yunius Wenda \\ Jenny Baroleh \\ Jean F. J. Timban
}

\begin{abstract}
The research objective was to assess community participation in each phase of activity in the PNPM Urban at Kleak Village, Malalayang District of Manado City. The method used is qualitative method, which examines the public participation at every stage and sustainability of PNPM Urban. Informants in this study amounted to 5 people on the basis that they can represent the object under study, consisting of: Head of the village, the board of the Institute for Community Empowerment (LPM), Community Self-Supporting Agency, Project Management Team / TPK PNPM Mandiri, and community members. The results showed that people at KleakVillage participated in the implementation of each phase of activity PNPM. It is shown from the community who donated labor, materials and equipment to build their physical environment, but in contributing to the fund are indeed not all community memberwho voluntarily donate. The research conclude that in the process of planning the activities of the National Program for Community Empowerment (PNPM Urban Selfhelp) community in the Kleak Village, had participated fairly well. Kleak Village communities already participating in the implementation of PNPM it is seen from the community who donated labor, materials and equipment to build their physical environment, but in contributing to the fund are indeed some who voluntarily contribute.
\end{abstract}

Keywords:Community participation, the National Program for Community Empowerment (PNPM Urban Selfhelp), Manado

\section{RINGKASAN}

Tujuan penelitian ialah untuk mengkaji partisipasi masyarakat dalam setiap tahapan dari kegiatan PNPM Mandiri Perkotaan di Kelurahan Kleak KecamatanMalalayang Kota Manado. Metode penelitian yang digunakan yaitu metode kualitatif, yakni mengkaji partisipasi masyarakat dalam setiap tahapan dan keberlanjutan kegiatan PNPM Mandiri Perkotaan. Informan dalam penelitian ini berjumlah 5 orang dengan pertimbangan bahwa mereka dapat mewakili objek yang diteliti, yang terdiri dari: Kepala Kelurahan, pengurus Lembaga Pemberdayaan Masyarakat (LPM), Badan Keswadayaan Masyarakat, Tim Pengelola Kegiatan/TPK PNPM Mandiri dan anggota masyarakat. Hasil penelitian menunjukkan bahwa masyarakat Kelurahan Kleak telan berpartisipasi dalam pelaksanaan setiap tahapan kegiatan PNPM. Hal ini ditunjukkan dari masyarakat yang memberikan bantuan berupa tenaga, bahan dan peralatan untuk membangun lingkungan mereka, namun dalam memberikan sumbangan dana memang beberapa orang saja yang secara sukarela memberi sumbangan. Penelitian ini menyimpulkan bahwa di dalam proses perencanaan kegiatan Program Nasional Pemberdayaan Masyarakat (PNPM-Mandiri Perkotaan) masyarakat di Kelurahan Kleak, sudah berpartisipasi dengan cukup baik. Masyarakat Kelurahan Kleak sudah berpartisipasi dalam pelaksanaan kegiatan PNPM hal ini terlihat dari masyarakat yang memberikan bantuan berupa tenaga, bahan dan peralatan untuk membangun lingkungan mereka, namun dalam memberikan sumbangan dana memang beberapa saja yang secara sukarela memberi sumbangan.

Kata kunci: Partisipasi masyarakat, Program Nasional Pemberdayaan Masyarakat (PNPM) Mandiri Perkotaan, Manado 


\section{PENDAHULUAN}

\section{Latar Belakang}

Tujuan pembangunan nasional yaitu untuk mewujudkan masyarakat adil dan makmur berdasarkan pancasila dan UUD 1945 dalam wadah Negara Kesatuan Republik Indonesia yang merdeka, berdaulat, bersatu dan berkedaulatan rakyat dalam suasana perikehidupan bangsa yang aman, tenteram, tertib, dan dinamis serta dalam lingkungan pergaulan dunia yang merdeka, bersahabat, tertib, dan damai. Tercapainya tujuan pembangunan nasional tersebut dibutuhkan antara lain keterlibatan atau peran serta dan kontribusi dari seluruh masyarakat.

Partisipasi masyarakat dalam pembangunan di negara sangatlah penting, diketahui bersama bahwa dalam hal ini masih merupakan masalah yang dihadapi oleh pemerintah di negara-negara tersebut, di negara ini partisipasi masyarakat masih tergolong lemah baik dari aspek semangat kesadaran maupun kemampuan. Lemahnya semangat dan kemampuan masyarakat dalam pembangunan, itu berhubungan erat dengan masalahmasalah seperti kemiskinan, serta keterbatasanketerbatasan yang dimiliki masyarakat, disamping itu juga ada hubungan dengan lemahnya kepemimpinan pemerintah dalam hal ini lurah atau kepala desa yang dapat mengubah serta menggairahkan tumbuhnya semangat berpartisipasi.

Tahun 2007 Pemerintah Republik Indonesia melalui presiden mencanangkan Program Nasional Pemberdayaan Masyarakat (PNPM) Mandiri sebagai salah satu kebijakan nasional penanggulangan kemiskinan dan penciptaan lapangan kerja, selain itu PNPM Mandiri dilaksanakan dengan pendekatan pemberdayaan masyarakat yang dimaksudkan untuk memperbaiki stabilitas sosial, membuka lapangan kerja, memperbaiki local govermance dan menciptakan aset untuk kelompok miskin. Kelompok masyarakat yang terbentuk dimaksudkan untuk menghilangkan marginalisasi penduduk miskin dan menjadi model jaringan pengaman sosial.

Melalui PNPM Mandiri masyarakat dituntut untuk dapat berpartisipasi aktif dalam setiap tahapan pelaksanaan program mulai dari tahap perencanaan, pelaksanaan kegiatan sampai pada tahap evaluasi maupun pemeliharaan, untuk mencapai harapan dimaksud tentu membutuhkan kerja keras dari semua pihak baik oleh pemerintah maupun masyarakat itu sendiri.

Pendekatan top-down yang dilakukan oleh pemerintah dalam pelaksanaan program pembangunan banyak mendapat kritik dari berbagai pihak karena dinilai pengaturan dalam pelaksanaan program semuanya dikendalikan oleh pemerintah lewat organisasi-organisasi sebagai pelaksana dan pengawas. Kondisi seperti ini dapat membuat masyarakat menjadi tidak berdaya dan tidak dilibatkan secara aktif. Kondisi masyarakat yang umumnya miskin dan tak berdaya membuat masyarakat tidak mampu untuk berpartisipasi secara aktif dalam pembangunan.

Kelurahan Kleak Kecamatan Malalayang terdiri dari 6 (enam) Lingkungan dengan jumlah penduduk berdasarkan data dari kantor lurah Kleak tahun 2014 berjumlah 5177 orang dengan jumlah keluarga1480 KK. Apabila ditinjau dari tingkat partisipasi masyarakat Kelurahan Kleak Kecamatan Malalayang Kota Manado dalam pembangunan secara keseluruhan masih lemah, baik dari aspek semangat kesadaran maupun kemampuan untuk berpartisipasi, disamping itu lemahnya pelaku-pelaku PNPM Mandiri perkotaan yang dapat menggugah serta menggairahkan tumbuhnya semangat berpartisipasi masyarakat. Untuk menjawab permasalahan di atas maka mendorong peneliti untuk melakukan suatu penelitian dengan sasaran kegiatan pembangunan prasarana fisik melalui kegiatan PNPM Mandiri Perkotaan di Kelurahan Kleak Kecamatan Malalayang Kota Manado. Di dalam penelitian ini dikaji bagaimana partisipasi masyarakat dalam tahapan perencanaan, pelaksanaan dan pelestarian kegiatan pembangunan.

\section{Konsep Pembangunan}

Istilah pembangunan bisa saja diartikan berbeda oleh satu orang dengan orang lain, daerah yang satu dengan daerah lainnya, negara satu dengan negara lain, namun secara umum ada suatu kesepakatan bahwa pembangunan merupakan proses untuk melakukan perubahan (Riyadi dan Bratakusumah, 2003).

Pembangunan (development) adalah proses perubahan yang mencakup seluruh sistem sosial, 
seperti politik, ekonomi, infrastruktur, pertahanan, pendidikan dan teknologi, kelembagaan, dan budaya (Alexander 1994). Portes (1996), mendefenisiskan pembangunan sebagai transformasi ekonomi, sosial dan budaya. Pembangunan adalah proses perubahan yang direncanakan untuk memperbaiki berbagai aspek kehidupan masyarakat.

\section{Manajemen Sumberdaya Manusia}

Manajemen sumber daya manusia (human resources management) adalah pendayagunaan, pengembangan, penilaian, pemberian balas jasa, dan pengelolaan individu anggota organisasi atau kelompok pekerja (Simamora, 2001). Manajemen sumber daya manusia itu merupakan aktivitas atau kegiatan yang dilakukan oleh sumber daya manusia di dalam suatu organisasi yang dapat digunakan secara efektif dalam mencapai berbagai tujuan.

Wahyudi (1996), mengungkapkan bahwa manajemen sumber daya manusia dapat diartikan sebagai ilmu dan seni atau proses memperoleh, memajukan atau mengembangkan dan memelihara tenaga kerja yang kompeten, sehingga tujuan organisasi dapat tercapai dengan efisien dan ada kepuasan pada diri pribadi yang bersangkutan. Pengertian tersebut menyebutkan bahwa pengelolaan sumber daya manusia dalam organisasi tidak hanya menyangkut hal mengenai ketenagakerjaan tetapi menjangkau lingkungan organisasi yang mempengaruhi sumber daya manusia sehingga dapat mencapai tujuan yang diinginkan. Tujuan pokok dari manajemen sumber daya manusia yaitu mewujudkan pendayagunaan secara optimal sumber daya manusia di dalam suatu organisasi.

\section{Partisipasi Masyarakat}

Partisipasi adalah keterlibatan seseorang dalam situasi baik secara mental, pikiran atau emosi dan perasaan yang mendorongnya untuk memberikan sumbangan dalam upaya untuk mencapai tujuan yang telah ditentukan dan ikut bertanggung jawab terhadap kegiatan pencapaian tujuan tersebut (Prasetya, 2008).

Partisipasi dapat diartikan sebagai keterlibatan masyarakat terhadap suatu kegiatan secara sukarela.Partisipasi sebagai bentuk komunikasi antar masyarakat maupun masyarakat dengan para staf yang melakukan persiapan, pelaksanaan, moni- toring suatu kegiatan agar memperoleh informasi mengenai konteks lokal dan dampak sosial. Soemarno dan Ismet (1999), mengungkapkan pendapatnya bahwa partisipasi tumbuh karena adanya dorongan dari diri manusia yang muncul karena kesadaran, tanpa adanya paksaan atau tekanan dari luar, karena partisipasi bersifat semu dan mudah berubah atau lenyap.

Tahap-tahap dari partisipasi masyarakat dapat terjadi dalam 4 (empat) jenjang, yaitu:"Participation in decision making, participation in implementation, participation in benefits, participation in evaluation." (Cohen and Uphoff's, 1980). Partisipasi dalam pembuatan suatu keputusan sangat diperlukan dikarenakan menyangkut nasib masyarakat sendiri. Tahap partisipasi kedua yaitu partisipasi dalam pelaksanaan. Partisipasi dapat dilakukan melalui keikutsertaan masyarakat dalam memberikan kontribusi guna menunjang pelaksanaan pembangunan yang berguna bagi pelaksana pembangunan.Tahapan partisipasi ketiga yaitu partisipasi dalam pemanfaatan hasil. Hasil dari setiap kegiatan hendaknya dapat dirasakan oleh masyarakat sebagai langkah untuk meningkatkan kesejahteraan masyarakat. Tahapan yang terakhir dari partisipasi dalam evaluasi. Setiap penyelenggara kehidupan bersama, dapat dinilai berhasil apabila dapat memberikan manfaat bagi masyarakat.

\section{PNPM Mandiri Perkotaan}

PNPM Mandiri Perkotaan merupakan program nasional dalam wujud kerangka kebijakan sebagai dasar dan acuan pelaksanaan programprogram penanggulangan kemiskinan berbasis pemberdayaan masyarakat. PNPM Mandiri dilaksanakan melalui harmonisasi dan pengembangan sistem serta mekanisme dan prosedur program, penyediaan pendampingan, dan pendanaan stimulan untuk mendorong prakarsa dan inovasi masyarakat dalam upaya penanggulangan kemiskinan yang berkelanjutan. Program-program yang tercakup dalam PNPM Mandiri adalah program-program penanggulangan kemiskinan dan penciptaan lapangan kerja yang berbasis pemberdayaan masyarakat dengan ciri-ciri: a) menggunakan pendekatan partisipasi masyarakat; b) melakukan penguatan kapasitas kelembagaan masyarakat; dan c) kegiatan 
program dilaksanakan secara swakelola oleh masyarakat.

Program Penanggulangan Kemiskinan di Perkotaan (P2KP) merupakan program pemerintah yang secara substansi berupaya dalam penanggulangan kemiskinan melalui konsep memberdayakan masyarakat dan pelaku pembangunan lokal lainnya, termasuk Pemerintah Daerah dan kelompok peduli setempat, sehingga dapat terbangun "gerakan kemandirian penanggulangan kemiskinan dan pembangunan berkelanjutan", yang bertumpu pada nilai-nilai luhur dan prinsip-prinsip universal (Dikutip dari : Buku Pedoman Umum P2KP-3, Edisi Oktober 2005).

Permasalahan kemiskinan di Indonesia sudah sangat mendesak untuk ditangani. Khususnya di wilayah perkotaan, salah satu ciri umum dari kondisi fisik masyarakat miskin adalah tidak memiliki akses ke prasarana dan sarana dasar lingkungan yang memadai, dengan kualitas perumahan dan permukiman yang jauh dibawah standar kelayakan, serta mata pencaharian yang tidak menentu. Disadari bahwa selama ini banyak pihak lebih melihat persoalan kemiskinan hanya pada tataran gejalagejala yang tampak terlihat dari luar atau di tataran permukaan saja, yang mencakup multidimensi, baik dimensi politik, sosial, ekonomi, aset dan lain-lain. Dalam kehidupan sehari-hari dimensi-dimensi dari gejala-gejala kemiskinan tersebut muncul dalam berbagai bentuk, seperti antara lain: Dimensi politik, sering muncul dalam bentuk tidak dimilikinya wadah organisasi yang mampu memperjuangkan aspirasi dan kebutuhan masyarakat miskin, sehingga mereka benar-benar tersingkir dari proses pengambilan keputusan penting yang menyangkut diri mereka. Akibatnya, mereka juga tidak memiliki akses yang memadai ke berbagai sumber daya kunci yang dibutuhkan untuk menyelenggarakan hidup mereka secara layak, termasuk akses informasi. Dimensi Sosial sering muncul dalam bentuk tidak terintegrasikannya warga miskin ke dalam institusi sosial yang ada, terinternalisasikannya budaya kemiskinan yang merusak kualitas manusia dan etos kerja mereka, serta pudarnya nilai-nilai kapital sosial. Dimensi Lingkungan sering muncul dalam bentuk sikap, perilaku, dan cara pandang yang tidak berorientasi pada pembangunan berkelanjutan sehingga cenderung memutuskan dan melaksanakan kegiatan-kegiatan yang kurang menjaga kelestarian dan perlindungan lingkungan serta permukiman; Dimensi Ekonomi muncul dalam bentuk rendahnya penghasilan sehingga tidak mampu untuk memenuhi kebutuhan hidup mereka sampai batas yang layak. dan Dimensi Aset, ditandai dengan rendahnya kepemilikan masyarakat miskin ke berbagai hal yang mampu menjadi modal hidup mereka, termasuk aset kualitas sumberdaya manusia (human capital), peralatan kerja, modal dana, hunian atau perumahan dan sebagainya.

Karakteristik kemiskinan seperti tersebut di atas dan krisis ekonomi yang terjadi telah menyadarkan semua pihak bahwa pendekatan dan cara yang dipilih dalam penanggulangan kemiskinan selama ini perlu diperbaiki, yaitu ke arah pengokohan kelembagaan masyarakat. Keberdayaan kelembagaan masyarakat ini dibutuhkan dalam rangka membangun organisasi masyarakat warga yang benar-benar mampu menjadi wadah perjuangan kaum miskin, yang mandiri dan berkelanjutan dalam menyuarakan aspirasi serta kebutuhan mereka dan mampu mempengaruhi proses pengambilan keputusan yang berkaitan dengan kebijakan publik di tingkat lokal, baik aspek sosial, ekonomi maupun lingkungan, termasuk perumahan dan permukiman.

Penguatan kelembagaan masyarakat yang dimaksud terutama juga dititikberatkan pada upaya penguatan perannya sebagai motor penggerak dalam 'melembagakan' dan 'membudayakan' kembali nilai-nilai kemanusiaan serta kemasyarakatan (nilainilai dan prinsip-prinsip di P2KP), sebagai nilainilai utama yang melandasi aktivitas penanggulangan kemiskinan oleh masyarakat setempat. Melalui kelembagaan masyarakat tersebut diharapkan tidak ada lagi kelompok masyarakat yang masih terjebak pada lingkaran kemiskinan, yang pada gilirannya antara lain diharapkan juga dapat tercipta lingkungan kota dengan perumahan yang lebih layak huni di dalam permukiman yang lebih responsif, dan dengan sistem sosial masyarakat yang lebih mandiri melaksanakan prinsip-prinsip pembangunan berkelanjutan.

Kepada kelembagaan masyarakat tersebut yang dibangun oleh dan untuk masyarakat, selanjutnya dipercaya mengelola dana abadi P2KP secara partisipatif, transparan, dan akuntabel. Dana tersebut dimanfaatkan oleh masyarakat untuk membiayai 
kegiatan-kegiatan penanggulangan kemiskinan, yang diputuskan oleh masyarakat sendiri melalui rembug warga, baik dalam bentuk pinjaman bergulir maupun dana waqaf bagi stimulan atas keswadayaan masyarakat untuk kegiatan yang bermanfaat langsung bagi masyarakat, misalnya perbaikan prasarana serta sarana dasar perumahan dan permukiman.

Model tersebut diharapkan mampu memberikan kontribusi untuk penyelesaian persoalan kemiskinan yang bersifat multi dimensional dan struktural, khususnya yang terkait dengan dimensi-dimensi politik, sosial dan ekonomi, serta dalam jangka panjang mampu menyediakan aset yang lebih baik bagi masyarakat miskin dalam meningkatkan pendapatannya, meningkatkan kualitas perumahan dan permukiman meraka maupun menyuarakan aspirasinya dalam proses pengambilan keputusan. Untuk mewujudkan hal-hal tersebut, maka dilakukan proses pemberdayaan masyarakat, yakni dengan kegiatan pendampingan intensif di tiap kelurahan sasaran.

Melalui pendekatan kelembagaan masyarakat dan penyediaan dana bantuan langsung ke masyarakat kelurahan sasaran, P2KP cukup mampu mendorong dan memperkuat partisipasi serta kepedulian masyarakat setempat secara terorganisasi dalam penanggulangan kemiskinan. Artinya, Program penanggulangan kemiskinan berpotensial sebagai "gerakan masyarakat", yakni; dari, oleh dan untuk masyarakat.

\section{Perumusan Masalah}

Berdasarkan uraian dalam latar belakang, maka yang menjadi perumusan masalah dalam penelitian ini yaitu bagaimana partisipasi masyarakat dalam tahapan perencanaan, pelaksanaan dan Evaluasi maupun pemeliharaan kegiatan PNPM Mandiri Perkotaan di Kelurahan Kleak Kecamatan Malalayang Kota Manado?.

\section{Tujuan Penelitian}

Tujuan penelitian ialah untuk mengkaji partisipasi masyarakat dalam tahapan perencanaan, pelaksanaan, dan evaluasi maupun pemeliharaan kegiatan PNPM Mandiri Perkotaan di Kelurahan Kleak Kecamatan Malalayang Kota Manado.

\begin{abstract}
Manfaat Penelitian
Manfaat yang diperoleh dari penelitian ini, yaitu:

a. Diharapkan akan memberikan manfaat dalam pengembangan teori khususnya yang berhubungan dengan teori Manajemen Pembangunan dalam kaitannya dengan partisipasi masyarakat.

b. Diharapkan akan memberikan masukan kepada lembaga-lembaga yang terkait khususnya pemerintah dalam merumuskan suatu kebijakan yang berkaitan dengan pemberdayaan masyarakat.
\end{abstract}

\section{METODE PENELITIAN}

\section{Metode Pengumpulan Data}

Metode penelitian yang digunakan yaitu metode kualitatif, dikarenakan peneliti mengkaji partisipasi masyarakat dalam tahapan perencanaan, pelaksanaan, dan pelestarian kegiatan PNPM Mandiri Perkotaan di Kelurahan Kleak Kecamatan Malalayang Kota Manado, berdasarkan hal tersebut maka metode kualitatif merupkan metode yang sesuai dengan tujuan penelitian. Moleong (2000) mengemukakan bahwa penelitian kualitatif adalah penelitian yang bermaksud untuk memahami fenomena tentang apa yang dialami oleh subjek penelitian misalnya perilaku, persepsi, motivasi, tindakan dan lain-lain., secara holistik dan dengan cara deskripsi dalam bentuk kata-kata dan bahasa pada suatu konteks khusus yang alamiah dan dengan memanfaatkan berbagai metode alamiah.

\section{Responden Penelitian}

Responden penelitian berjumlah lima orang dengan pertimbangan bahwa mereka dapat mewakili objek yang diteliti, yang terdiri dari : (1) Kepala kelurahan, (2) pengurus LPM, (3) Badan Keswadayaan Masyarakat, (4) Timke Pengelola kegiatan/TPK, sebagaiketua pengurus PNPM dan (5) anggota masyarakat.

\section{Sumber Data}

Data primer diperoleh dari pengamatan langsung dan wawancara dengan membandingkan data yang diperoleh melalui wawancara dengan responden. Dalam penelitian ini dilengkapi juga dengan data sekunder berupa laporan, maupun arsip 
yang diperoleh dari pemerintah kecamatan dan kelurahan maupun dokumen atau literatur pendukung yang berkaitan dengan permasalahan dan tujuan penelitian.

\section{Teknik Pengumpulan Data}

Berdasarkan tujuan yang hendak dicapai dalam penelitian ini, maka dipergunakan tahap-tahap yang sesuai dengan kebutuhan penelitian. Proses analisa data yang digunakan dalam menganalisa partisipasi masyarakat dalam kegiatan PNPM Mandiri Perkotaan ialah analisis kualitatif.

Metode pengumpulan data dalam penelitian ini dilakukan dengan wawancara dan observasi.

\section{Fokus Penelitian}

Penelitian ini difokuskan terhadap partisipasi masyarakat dalam kegiatan PNPM Mandiri Perkotaan di Kelurahan Kleak Kecamatan Malalayang Kota Manado yang meliputi : Tahapan perencanaan kegiatan lingkungan, pelaksanaan kegiatan lingkungan dan pemeliharaan hasil kegiatan lingkungan PNPM Mandiri Perkotaan.

\section{Teknik Analisis Data}

Teknik analisis data yang digunakan dalam penelitian ini yaitu secara deskriptif.

\section{Waktu dan Tempat Penelitian}

Penelitian ini berlangsung selama dua bulan yakni bulan Juni dan Juli 2015 dimulai dari persiapan sampai penyusunan laporan hasil penelitian. Tempat penelitian dilaksanakan di Kelurahan Kleak Kecamatan Malalayang Kota Manado.

\section{HASIL DAN PEMBAHASAN}

\section{Gambaran Umum Kelurahan Kleak}

Kelurahan Kleak merupakan salah satu dari 9 kelurahan yang berada di Kecamatan Malalayang. Kelurahan Kleak merupakan hasil pemekaran dari Desa Bahu Kecamatan Sario pada tahun 1978, yang pada waktu itu Desa Bahu dibagi menjadi dua desa, yaitu Desa Bahu dan Desa Kleak. Sesuai dengan Keputusan Menteri Dalam Negeri Nomor 140 Tahun 1981, maka status desa yang berada di Kotamadya dan di Ibu Kota Kabupaten berubah menjadi Ke- lurahan, dimana Desa Kleak berubah menjadi Kelurahan Kleak Kecamatan Malalayang, yang terdiri dari 5 Lingkungan.

Tabel 1. Pimpinan Kelurahan Kleak yang memimpin sejak tahun 1978-2015

\begin{tabular}{|c|c|c|c|}
\hline No. & Nama & Periode & Status \\
\hline 1 & Weliam J. Kalesaran & $1978-1985$ & $\begin{array}{l}\text { Kepala } \\
\text { Desa }\end{array}$ \\
\hline 2 & Herny R. Watuseke & $1985-1987$ & Lurah \\
\hline 3 & Robert Rumuat & 1987-1991 & Lurah \\
\hline 4 & Poltje Runturambi & $1991-2000$ & Lurah \\
\hline 5 & Drs. Jusak Laleleh & $2000-2001$ & Lurah \\
\hline 6 & Drs. Serpius R. Kandou & 2001-2006 & Lurah \\
\hline 7 & $\begin{array}{l}\text { Adrianus J. Taroreh, } \\
\text { SE }\end{array}$ & 2006-2008 & Lurah \\
\hline 8 & Lucky Walangare, S.IP & 2008-2009 & Lurah \\
\hline 9 & $\begin{array}{l}\text { Dra. Catotje } \\
\text { Wowiling }\end{array}$ & $\begin{array}{l}2009 \\
\text { Sekarang }\end{array}$ & Lurah \\
\hline
\end{tabular}

Sumber: Kantor Kelurahan Kleak, Tahun 2015

Pada Tahun 2001 Kelurahan Kleak dimekarkan menjadi dua kelurahan, yaitu Kelurahan Kleak dan Kelurahan Batukota.Sekarang ini Kelurahan Kleak telah menjadi salah satu kelurahan dari 87 kelurahan yang ada di Kota Manado.

Adapun pemimpin Desa/Kelurahan Kleak yang memimpin sejak Tahun 1978 terdapat daspal Tabel 1.

\section{Geografi Kelurahan}

Kelurahan Kleak berada di wilayah administrasi Kecamatan Malalayang Kota Manado dengan batas-batas sebagai berikut :

- Sebelah Utara berbatasan dengan Kelurahan Sario Tumpaan/Ranotana

- Sebelah Selatan berbatasan dengan Kelurahan Batu Kota

- Sebelah Timur berbatasan dengan Kelurahan Karombasan Utara

- Sebelah Barat berbatasan dengan Kelurahan Bahu

Letak Kelurahan Kleak terhadap pusat-pusat fasilitas kota adalah :

a. Jarak tempuh dengan Ibu Kota Kecamatan 4 km dengan jarak tempuh 15 menit dengan menggunakan kendaraan bermotor. 
b. Jarak tempuh dengan Ibu Kota Manado $8 \mathrm{~km}$ dengan jarak tempuh 30 menit dengan menggunakan kendaraan bermotor.

c. Jarak tempuh dengan Ibu kota Provinsi $5 \mathrm{~km}$ dengan jarak tempuh 25 menit dengan menggunakan kendaraan bermotor.

Adapun luas wilayah Kelurahan Kleak adalah 60,37 ha yang terbagi dalam 6 Lingkungan dengan rincian sebagai berikut :

- Lingkungan I dengan luas wilayah 10,80 ha

- Lingkungan II dengan luas wilayah 20 ha

- Lingkungan III dengan luas wilayah 8,44 ha

- Lingkungan IV dengan luas wilayah 6,94 ha

- Lingkungan V dengan luas wilayah 5,23 ha

- Lingkungan VI dengan luas wilayah 3,95 ha

\section{Topografi Kelurahan}

Kondisi topografi wilayah Kelurahan Kleak berada pada dataran rendah. Adapun keadaan iklimnya untuk suhu terpanas $31^{\circ} \mathrm{C}$ dengan sifat angin pada umumnya sejuk dan curah hujan ratarata 1500 - $2000 \mathrm{~mm}$, dengan ketinggian dari permukaan laut 20 - $50 \mathrm{~m}$.

\section{Demografi Kelurahan}

Kelurahan Kleak sampai dengan akhir bulan Desember 2014 jumlah Kepala Keluarga 1480 KK dengan jumlah penduduk 5177 jiwa. Penduduk menurut jenis kelamin, agama dan mata pencaharian dirinci sebagai berikut :

1. Penduduk menurut jenis kelamin :

- Laki-laki 2552 jiwa

- Perempuan 2625 jiwa

Jumlah penduduk perempuan lebih banyak dari jumlah penduduk laki-laki.

2. Penduduk menurut kepercayaan agama :

- Islam 653 jiwa

- Kristen 3530 jiwa

- Katholik 679 jiwa

- Hindu 4 jiwa

- Budha 10 jiwa

Jumlah penduduk yang memeluk agama Kristen merupakan jumlah tertinggi.

3. Penduduk menurut mata pencaharian terdapat pada Tabel 2. Tabel 2 menunjukkan bahwa mata pencaharian sebagai PNS merupakan mata pencharian yang memiliki jumlah penduduk tertinggi.
Tabel 2. Penduduk menurut mata pencaharian

\begin{tabular}{|c|c|}
\hline Mata Pencaharian & $\begin{array}{l}\text { Jumlah } \\
\text { (jiwa) }\end{array}$ \\
\hline - Pegawai Negeri Sipil & 302 \\
\hline - Guru & 89 \\
\hline - Dosen & 76 \\
\hline - TNI / Polri & 19 \\
\hline - Wiraswasta & 205 \\
\hline $\begin{array}{l}\text { - Pengusaha Kecil dan Menen- } \\
\text { gah }\end{array}$ & $\begin{array}{c}62 \\
4\end{array}$ \\
\hline - Pengacara & 37 \\
\hline - Dokter & 12 \\
\hline - Perawat & 1 \\
\hline - Bidan & 2 \\
\hline - Petani & 175 \\
\hline - Pensiunan PNS/TNI/Polri & 188 \\
\hline - Karyawan Perusahaan & 33 \\
\hline - Karyawan & 1 \\
\hline Pemerintah & 2 \\
\hline - Notaris & 32 \\
\hline - Montir & 34 \\
\hline - Sopir & 21 \\
\hline - Tukang Ojek & 9 \\
\hline - Tukang Kayu/Batu & 4 \\
\hline - Pedagang Keliling & 4 \\
\hline - Tukang Cuci & 4 \\
\hline - Pengrajin & 2 \\
\hline - Pedagang Kelontong & 142 \\
\hline - Nelayan & \\
\hline - Miskin & \\
\hline
\end{tabular}

Sumber : Kantor Kelurahan Kleak, Tahun 2015

\section{Partisipasi Masyarakat dalam Kegiatan PNPM} Berdasarkan hasil wawancara dengan informan dalam hal ini Ketua PNPM Mandiri Perkotaan di Kelurahan Kleak Kecamatan Malalayang maka jenis-jenis kegiatan sebagai berikut :

1). Pembuatan Jalan setapak (di lingkungan I)

Pembuatan jalan setapak dengan panjang 150 meter dengan anggaran $\quad \mathrm{Rp} 27.000 .000$ dan partisipasi masyarakat Rp 3000.000, tahun anggaran 2012.

Pembuatan jalan setapak ini di lakukan selama 30 hari kerja panitia pelaksana di bentuk dengan 1 orang Ketua, 1 orang sekretaris, 1 orang bendahara dan 5 orang anggota. Pekerjaan ini di- 
awali dengan Rapat Anggota untuk membicarakan partisipasi masyarakat untuk memenuhi anggaran $\mathrm{Rp} 3000.000$

Disepakati dalam rapat tersebut dalam bentuk tenaga dan sumbangan material dan bahan lainnya. Pekerjaan ini diawali dengan pembelian material kemudian semua material terpenuhi maka mulailah proses pembuatan jalan setapak.

Jumlah pekerja sebanyak 5 orang yang merupakan anggota masyarakat penerima manfaat jalan tersebut pekerjaan ini di lakukan setiap hari dari pagi sampai sore.

2). Pembuatan Jalan Paving Block.

Pembuatan jalan Paving Block dengan panjang 70 meter dan lebar 2 meter, dengan anggaran 36.000 .000 di tambah dengan partisipasi masyarakat Rp 4000.000 (tahun anggaran 2014).

3). Pembuatan jalan Paving Block dan Talut.

Pembuatan jalan Paving Block dengan ukuran 3 meter panjang 7 meter dengan anggaran 27 juta, partisipasi masyarakat Rp 3000.000, tahun anggaran 2014.

Kemudian pembuatan jalan setapak dan talut, dengan ukuran talutnya 7 meter, tingginya 2 meter di tambah dengan Relling, tahun anggaran 2013.

4). Pembuatan Bak Penampungan Air ( di lingkungan VI).

Pembuatan bak penampungan air dengan anggaran Rp 40.000.000, ditambah dengan partisipasi masyarakat Rp 5000.000 dengan pompa air dan pembuatan pipa saluran air dengan panjang 30 meter.

Untuk tahun 2015 belum ada realisasi anggaran disebabkan karena ada perubahan nomenklatur dari PNPM menjadi P2KP dimana tahun ini menjadi tahun sosialisasi.

a. Partisipasi Masyarakat dalam Perencanaan Kegiatan

Hasil penelitian berdasarkan wawancara dengan pengurus PNPM Mandiri Perkotaan Kelurahan Kleak, menunjukkan bahwa di dalam proses perencanaan kegiatan PNPM seluruh masyarakat sudah diundang untuk berpartisipasi. Menurut infotman, pelaksanaan PNPM Mandiri memerlukan dukungan dari berbagai pihak meliputi:
(1). Lembaga yang mendukung dari aspek kebijakan seperti DPR, DPRD, Pemerintah Daerah. Posisi Pemerintah dan DPRD dalam hal ini menjadi dominan, sebab PNPM Mandiri sebagai program pemerintah (pusat) akan memiliki fase akhir dan diteruskan menjadi program pemerintah daerah.

(2). Lembaga yang mendukung terjadinya partisipasi untuk mengembangkan dan mereplikasi program, seperti lembaga donor, bantuan dunia usaha/industri.

(3) Pihak-pihak yang memberikan dukungan publik dari kelompok peduli yaitu kelompok profesional, lembaga swadaya masyarakat, organisasi kemasyarakatan, lembaga atau kelompok peduli lainnya dan masyarakat. Berdasarkan hal tersebut maka terlihat pentingnya partisipasi masyarakat dalam keseluruhan proses kegiatan PNPM Mandiri perkotaan.

Informan lainnya berpendapat bahwa sangat penting dalam suatu kegiatan melibatkan masyarakat, karena apa yang akan dibangun khususnya kegiatan lingkungan dari Program PNPM menyangkut kepentingan masyarakat, sehingga apa yang masyarakat harapkan dapat terealisasikan jika masyarakat dapat berpartisipasi aktif dalam perencanaan keseluruhan program PNPM.

Kegiatan Lingkungan yang dilaksanakan melalui Kelompok Swadaya Masyarakat (KSM) merupakan salah satu bagian pelaksanaan yang didanai program PNPM Mandiri Perkotaan secara stimulan untuk mengentaskan dan memperbaiki kualitas hidup masyarakat miskin. PNPM Mandiri Perkotaan hanya menyediakan alternatif kegiatan pembangunan lingkungan, namun masyarakat sendiri yang menentukan jenis dan bentuk kegiatan prasarana dan sarana agar sejalan dengan kebutuhan dalam rangka pengentasan kemiskinan.

Partisipasi pada tahap perencanaan ialah keikutsertaan masyarakat dalam penyusunan rencana suatu kegiatan. Tahap perencanaan, yang dinilai ialah kehadiran masyarakat dalam perencanaan program dan keterlibatan dalam mengemukakan pendapat dan terlibat dalam identifikasi kebutuhan.

Informan lainnya menjelaskan akan tahapan perencanaan dan juga bagaimana keterlibatan masyarakat. Pada tahap perencanaan, pihak PNPM Mandiri selaku fasilitator melakukan diskusi dengan beberapa perwakilan dari pihak masyarakat dan biasanya yang hadir dalam diskusi ini ialah para tokoh masyarakat. Selain itu, yang hadir dalam diskusi ini 
selain pihak PNPM dan perwakilan masyarakat ialah pihak Badan Keswadayaan Masyarakat (BKM), Unit Pengelola Lingkungan (UPL), serta pihak kelurahan. Diskusi dilakukan untuk merumuskan kebutuhan masyarakat secara bersama-sama serta menentukan apakah program ini sudah sesuai dengan kebutuhan masyarakat atau belum.

Diskusi dilakukan untuk menentukan lokasi mana saja yang layak menerima bantuan dana dari program ini. Pihak PNPM mengirimkan undangan kepada para tokoh masyarakat dan pemerintah untuk menghadiri rapat yang diadakan di kantor kelurahan. Setelah pihak PNPM mengadakan rapat dengan tokoh masyarakat dan pemerintah, pihak PNPM pun mengadakan rapat dengan masyarakat. Rapat yang dilakukan bersama masyarakat dilaksanakan di masingmasing lingkungan.

Partisipasi masyarakat dalam perencanaan program selaku penerima program tergolong sedang. Hal ini dikarenakan masyarakat penerima program hanya memberikan sedikit masukan ketika diskusi dilaksanakan. Selain itu, masyarakat tidak selalu hadir dalam rapat perencanaan yang dilaksanakan oleh pihak PNPM.

Penelitian selanjutnya menunjukkan bahwa di dalam proses perencanaan penentuan program, semua masyarakat yang diundang hadir untuk mengikuti rapat. Menurut informan, di dalam kelurahan banyak sekali kebutuhan-kebutuhan masyarakat khususnya kebutuhan untuk pembangunan, akan tetapi tentu saja tidak semua kebutuhan akan pembangunan dapat langsung terpenuhi, semuanya membutuhkan proses. Di dalam tahap perencanaan pembangunan, pertemuan untuk menentukan prioritas pembangunan sangatlah penting. Di dalam program ini, biasanya semua kebutuhan akan pembangunan dari masyarakat didata dalam program jangka menengah program penanggulangan kemiskinan (PJM Pronankis), akan tetapi apa yang tertuang dalam PJM pronankis ini tidak semuanya langsung dapat direalisasikan. Sebelum pelaksanaan pembangunan, diadakan dulu pertemuanpertemuan antara pihak fasilitator PNPM, pemerintah, LKM dan masyarakat yang menentukan mana kegiatan priorotas yang akan dilaksanakan, serta di lokasi mana akan dilaksanakan, semuanya didiskusikan, untuk itulah sangat penting adanya partisipasi aktif dari masyarakat, karena tanpa adanya partisipasi aktif dari masyarakat maka tujuan dari program ini tidak akan bisa tercapai.
Hasil penelitian menunjukkan bahwa didalam proses perencanaan masyarakat sudah cukup baik dalam memberikan ide-ide guna kemajuan pembangunan. Menurut informan dengan adanya ide-ide dari masyarakat maka apa yang menjadi tujuan dan sasaran dari program ini akan tercapai dan benarbenar bermanfaat bagi masyarakat.

Jenis kegiatan lingkungan atau infrastruktur atau sarana dan prasarana yang dibangun oleh KSM/panitia dalam PNPM Mandiri Perkotaan pada dasarnya bersifat sangat fleksibel sesuai usulan/kebutuhan masyarakat, terutama kegiatan perbaikan dan pembangunan sarana/prasarana perumahan dan permukiman baik untuk kepentingan umum (kolektif) maupun kepentingan individu masyarakat miskin. Semua jenis kegiatan yang akan dilaksanakan tersebut haruslah memenuhi persyaratan kelayakan teknis.

Menurut informan di Kelurahan Kleak kegiatan lingkungan yang paling banyak diusulkan yaitu menyangkut prasarana air bersih, hal ini dikarenakan letak dan lokasi dari Kelurahan Kleak yang jika hanya mengharapkan air dari PDAM tidak akan mecukupi sehingga sangat dibutuhkan adanya tambahan pembangunan prasarana air bersih.

Secara umum mekanisme pelaksanaan kegiatan yang dilakukan oleh KSM/panitia dalam pelaksanaan kegiatan pembangunan sarana dan prasarana, mencakup 3 tahapan yaitu a) tahap persiapan dan perencanaan teknis, b) tahap pelaksanaan pembangunan dan c) tahap pasca konstruksi (pemanfaatan dan pemeliharaan).

Hasil penelitian selanjutnya menunjukkan bahwa partisipasi masyarakat dalam proses perencanaan memang sudah cukup baikakan tetapi ada yang menjadi permasalahan yaitu kurangnya informasi kepada masyarakat tentang program PNPM mandiri perkotaan. Informasi yang lengkap dan utuh merupakan suatu modal penting bagi masyarakat untuk memahami dengan baik tentang pentingnya program pemberdayaan dalam hal ini Program Nasional Pemberdayaan Masyarakat Mandiri Perkotaan bagi seluruh masyarakat. Pemahaman yang baik dan tepat akan mengembangkan kesadaran masyarakat untuk lebih berpartisipasi secara aktif demi pembangunan. PNPM-MP ini bertujuan untuk meningkatkan kesejahteraan dan kesempatan kerja bagi masyarakat miskin dengan mendorong kemandirian dalam 
pengambilan keputusan dan pengelolaan pembangunan. Pada dasarnya, pemberdayaan muncul dikarenakan adanya kondisi sosial ekonomi yang rendah pada masyarakat yang memberi akibat tidak mampu dan tidak tahu atau akses informasi minim. Mereka tidak dapat menikmati pendidikan yang memadai. Sehingga akibat dari semuanya itu produktivitas masyarakat pun menjadi rendah.Kesadaran terhadap keadaan ini menjadi sangat penting untuk bisa melakukan perubahan ke arah keberdayaan dan kemandirian.

b. Partisipasi Masyarakat dalam Pelaksanaan Kegiatan

Hasil penelitian mununjukkan bahwa masyarakat sudah turut serta dalam pelaksanaan kegiatan PNPM. Masyarakat sudah berpartisipasi dalam menunjang pelaksanaan kegiatan PNPM. Menurut informan, partisipasi pada tahap pelaksanaan program merupakan keikutsertaan dan keaktifan dalam pelaksanaan kegiatan program pengembangan masyarakat yang dilakukan oleh pihak PNPM, BKM, dan UPL. Partisipasi diukur berdasarkan banyaknya kegiatan yang diikuti responden, akses dan kontrol terhadap program, keterlibatan dalam pengambilan keputusan. Pihak PNPM selaku penanggungjawab keseluruhan program $\mathrm{PEB}$ PNPM-MP memberikan akses kepada masyarakat untuk menentukan kegiatan yang dirasakan menjadi prioritas untuk dilaksanakan.

Berpendapat bahwa tanpa adanya partisipasi aktif dari masyarakat maka kegiatan lingkungan di kelurahan tidak akan bisa berjalan dengan baik. Di dalam program PNPM Mandiri perkotaan suatu kegiatan lingkungan akan bisa dilaksanakan jika sudah ada persetujuan partisipasi masyarakat sebesar $30 \%$ dari total anggaran yang dibutuhkan, partisipasi masyarat berupa tenaga kerja, bahan ataupun pemberian makanan kepada para pekerja. Jika masyarakat sudah menyanggupinya maka partisipasi tersebut dicatat dalam proposal dan ditandatangani di atas meterai oleh pihak masyarakat dan juga KSM (kelompok swadaya masyarakat) yang dipercayakan untuk pembangunan kegiatan lingkungan tersebut.

Menurut informan, partisipasi masyarakat pada tahap persiapan dan perencanaan teknis sudah cukup baik, masyarakat yang diwakili oleh KSM, selalu berusaha mempersiapkan semua persyaratan agar supaya proses pelaksanaan kegiatan dapat berjalan dengan baik dan sesuai dengan apa yang menjadi perencanaan. Akan tetapi ada informan yang berpendapat bahwa terkadang ada sebagian masyarakat yang sangat sulit untuk diajak bekerja sama, walaupun sebenarnya kegiatan yang akan dibangun bermanfaat langsung kepada mereka. Contohnya, masyarakat sulit untuk memberikan tenaga pada saat pelaksaan pembersihan lokasi proyek, tentunya ini akan sangat menghambat pelaksaan kegiatan kedepan, karena jika semua tenaga kerja harus dibayar, maka tidak mungkin dana yang diberikan oleh pihak PNPM mandiri akan mencukupi.

Baik KSM sebagai pelaksana kegiatan lingkungan maupun kegiatan lingkungan yang diusulkan oleh KSM untuk dilaksanakan melalui PNPM Mandiri Perkotaan umumnya sudah memenuhi persyaratan yang telah ditetapkan oleh program.

Informan lainnya berpendapat bahwa partisipasi masyarakat dalam pelaksanaan program PNPM mandiri perkotaan kurang maksimal, hal ini dikarenakan umumnya apa yang menjadi kesepaka$\tan 30 \%$ partisipasi masyarakat dalam kegiatan lingkungan hanyalah di atas kertas, akan tetapi pada kenyataannya tidak dilaksanakan. Hal ini terlihat dari umumnya para pekerja walaupun untuk mambangun lingkungannya sendiri mereka harus meminta upah, padahal sebenarnya mereka dapat memberikan sumbangan tenaga agar nantinya kegiatan lingkungan yang sementara dilaksanakan dapat lebih baik kwalitasnya. Akan tetapi karena tidak adanya partisipasi masyarakat maka pihak KSM berupaya untuk membuat dana yang diberikan cukup untuk pembangunan, sehingga terkadang kualitas yang dihasilkan kurang, hal ini tentunya akan sangat merugikan masyarakat itu sendiri, karena manfaat dari pembangunan tersebut tidak akan bisa lama dimanfaatkan oleh masyarakat. Ada beberapa masyarakat yang sulit diajak kerja bakti disebabkan karena banyak orang yang sudah kerja membantu melaksanakan pekerjaan atau projek tersebut, sehingga mereka enggan untuk turun langsung dalam kegiatan.

Pelaksanaan kegiatan pembangunan sarana dan prasarana lingkungan umumnya sudah didu- 
kung oleh berbagai pihak seperti BKM, UPL, serta masyarakat penerima manfaat langsung yaitu warga miskin dan warga sekitar. KSM/Panitia sebagai pelaksana pembangunanpun akan didukung peran sertanya oleh Fasilitator Kelurahan.

\section{c. Partisipasi Masyarakat dalam Pemeliharaan Kegiatan}

Hasil penelitian menunjukkan bahwa masyarakat turut serta dalam proses pelestarian hasil pembangunan lewat program PNPM. Informan berpendapat bahwa, kesadaran masyarakat untuk berpartisipasi memelihara hasil pembangunan lewat kegiatan lingkungan pada program PNPM mandiri perkotaan sudah cukup baik, karena masyarakat menyadari akan arti penting dari hasil pembangunan tersebut. Informan memberikan contoh, ada sebuah pembangunan jalan setapak dari beton, seiring berjalannya waktu mulai terdapat kerusakan kecil. Karena masyarakat menyadari akan pentingnya jalan setapak tersebut, maka masyarakat secara bergotong royong selalu memperbaiki kerusakan tersebut agar tidak semakin membesar, sehingga jalan beton tersebut dapat awet dan dapat digunakan masyarakat.

Penyiapan organisasi pengelola pemanfaatan dan pemeliharaan prasarana disini mencakup kegiatan (1). pembentukan organisasi pengelola (struktur organisasi) termasuk penentuan orangorang yang akan bertanggungjawab pada setiap unit kerja, (2). Penyusunan rencana kerja pemanfaatan dan pemeliharaan.

Pada prinsipnya semua prasarana yang telah dibangun harus dipelihara, namun demikian, mengingat pemanfaat setiap prasarana tidak seluruhnya sama maka pembentukan/pengorganisasian disini hanya diprioritaskan pada prasarana yang bersifat umum/publik dan prasarana kelompok, sedangkan untuk prasarana yang bersifat individu atau penggunaan oleh satu keluarga saja, tidak perlu dibentuk organisasi pengelolanya, seperti jamban keluarga, saluran limbah rumah tangga, karena sudah langsung dipelihara oleh masing-masing keluarga pengguna.

Informan lainnya berpendapat bawa ada sebagian masyarakat yang tidak mau berpartisipasi dalam kegiatan pemeliharaan hasil pembangunan lewat kegiatan lingkungan pada program PNPM
Mandiri Perkotaan, hal ini dikarenakan kurangnya kesadaran masyarakat akan arti penting pembangunan tersebut, walaupun sebenarnya masyarakat turut menggunakan hasil pembangunan tersebut.

Salah satu kegiatan penting dari seluruh proses PNPM Mandiri Perkotaan, khususnya pada pendekatan pelaksanaan kegiatan lingkungan ini ialah kegiatan pemanfaatan dan pemeliharaan (atau Operasi dan Pemeliharaan, disingkat O\&P) yang dilakukan melalui inisiatif dan kesadaran masyarakat oleh KSM/Pengelola O\&P sebagai penggerak utama dari kegiatan ini.

Hampir semua pembangunan prasarana yang selesai dibangun ternyata mengalami kerusakan karena tidak terpelihara. Hal ini kemungkinan disebabkan tidak tersedianya dana rehabilitasi dari sektor/instansi terkait, tidak ada swadaya masyarakat untuk pemeliharaan dan belum adanya kesadaran masyarakat untuk memelihara prasarana tersebut, sehingga manfaat yang diterima oleh masyarakat dengan adanya pembangunan prasarana tersebut tidak optimal dan belum berkelanjutan. Walaupun dapat dinikmati akan tetapi jangka waktu pemanfaatannya menjadi terbatas (kurang dari umur yang direncanakan). Selain itu, kualitas prasarana yang dibangun menjadi kurang terjamin dan harapan diperolehnya manfaat yang berkelanjutan tidak dapat tercapai.

Apabila prasarana yang dibangun tidak memberikan manfaat jangka panjang akibat lemahnya pengelolaan, akan berakibat pada tidak tercapainya harapan masyarakat dan tujuan program. Karena itu perlu adanya ketegasan, penanggungjawab dan rencana pengelolaan (pemanfaatan dan Pemeliharaan) prasarana yang baik sesuai kebutuhan terhadap sarana dan prasarana yang telah dibangun.

\section{KESIMPULAN DAN SARAN}

\section{Kesimpulan}

1. Dalam proses perencanaan kegiatan Program Nasional Pemberdayaan Masyarakat (PNPMMandiri Perkotaan) masyarakat di Kelurahan Kleak, sudah berpartisipasi dengan cukup baik hal ini terlihat pada proses perencanaan masyarakat sudah berperan aktif serta sudah 
cukup baik dalam memberikan ide-ide guna kemajuan pembangunan.

2. Masyarakat Kelurahan Kleak sudah berpartisipasi dalam pelaksanaan kegiatan PNPM hal ini terlihat dari masyarakat yang memberikan bantuan berupa tenaga dan peralatan untuk membangun lingkungan mereka, namun dalam memberikan sumbangan dana memang beberapa saja yang secara sukarela memberi sumbangan. Setelah selesainya pelaksanaan kegiatan maka masyarakat dapat memanfaatkan hasil kegiatan tersebut dan umumnya masyarakat sangat merasa terbantu dengan dilaksanakannya kegiatan PNPM di lingkungannya.

3. Masyarakat di kelurahan Kleak turut serta dalam proses pemeliharaan hasil pembangunan lewat program PNPM. Hal ini disebabkan karena masyarakat ingin hasil pembangunan bisa bertahan lama, dan dimanfaatkan di lingkungan mereka, sehingga masyarakat secara bergotong royong memelihara seluruh hasil pembangunan yang ada.

\section{Saran}

1. Untuk meningkatkan partisipasi masyarakat pada PNPM Mandiri Perkotaan di kelurahan kleak diperlukan peran semua pihak yang terkait terutama mengajak masyarakat untuk menghadiri pertemuan-pertemuan yang diadakan. Hal ini akan membuat masyarakat lebih paham akan tujuan dan sasaran program yang telah dilaksanakan.

2. Fasilitator sebagai motor penggerak masyarakat lebih aktif lagi dan sebaiknya tetap di lokasi kegiatan dalam tahun berjalannya kegiatan. Di samping fasilitator PNPM sebaiknya juga dibantu oleh tenaga pemberdayaan masyarakat dari pemerintah daerah.

\section{DAFTAR PUSTAKA}

Alexander 1994. Portes (1996), Pembangunan Sebagai Transformasi Ekonomi, Sosial dan Budaya.
Anwar, A.M. 2005. Sumber Daya, Teknologi dan Pembangunan, PT. Gramedia Pustaka Utama, Jakarta.

Cohen J.M. and Uphoff. 1980. Rural Development Participation. New York. Itacha.

Gomes, F., 2003. Manajemen Sumber Daya Manusia. Penerbit Andi. Yogyakarta.

Prasetyo, B., 2008. Metode Penelitian Kuantitatif: Teori dan Aplikasi. Jakarta: PT. Raja Grafindo Persada.

Riyadi, D. dan S. Bratakusumah, 2003. Perencanaan Pembangunan Daerah. Rajawali : Jakarta.

Simamora, H., 2001. Manajemen Sumber Daya Manusia. Cetakan 3, STIE YKPN. Yogyakarta.

Siagian, S.P., 1994. Proses Pengelolahan Pembangunan Nasional. Penerbit CV. Haji Masagung, Jakarta.

Sumardi, M., 2005. Kemiskinan dan Kebutuhan Pokok, CV. Rajawali Jakarta

Sulistiyani, A.T. dan Rosidah., 2003. Manajemen Sumber Daya Manusia. Graha Ilmu: Yogyakarta.

Suharto, E., 2005. Membangun Masyarakat Memberdayakan Rakyat, Bandung Refika Aditama.

Wahyudi. 1996, Manajemen Sumber Daya Manusia.

Soemarno dan Ismet. 1999. Partisipasi Tumbuh karena Adanya Dorongan Dari Diri Manusia Yang Muncul Karena Kesadaran. 